\title{
Diastatic activity in some unifloral honeys
}

\author{
L Persano Oddo ${ }^{1^{*}}$, E Baldi 2, M Accorti 1 \\ 1 Istituto Sperimentale per la Zoologia Agraria, Sezione di Apicoltura, \\ Via Leonida Rech 36, 00156 Roma; \\ 2 Istituto di Industrie Agrarie, Università degli Studi - Via S Michele degli Scalzi 4, 56100 Pisa, Italy
}

(Received 31 July 1988; accepted 20 June 1989)

\begin{abstract}
Summary - Determinations of diastatic activity in 12 groups of unifloral honey were made to study variability according to the botanical origin of the honey. Robinia, Citrus, Erica, Taraxacum and Arbutus honeys were found to have a very low enzyme content. On the contrary Hedysarum, Castanea, Honeydew, Eucalyptus and Thymus honeys showed high diastase activity. The relationship between the absorbance at $5 \mathrm{~min}$ and the diastatic index was quantified.
\end{abstract}

honey / enzyme activity / amylase / absorbance

\section{INTRODUCTION}

The presence of enzymes in honey has been known for many years. One of the better known enzymes is diastase or amylase. The origin of this enzyme in honey has been attributed to the salivary secretions of bees (Gothe, 1914), or to its presence in pollen (Vansell and Freeborn, 1929; Lothrop and Paine, 1931), or nectar (Fiehe, 1932; Gorbach, 1942). Today, the most widely accepted theory attributes the origin of diastase in honey to salivary secretions of bees. This conclusion is based on the presence of diastase in honey produced by sugar-fed bees, and on the similarity between honey diastase and bee diastase (Ammon, 1949; Rinaudo et al, 1973; Stadelmeier and Bergner, 1986). Howev$\mathrm{er}$, this does not explain why honeys of diverse botanical origin show a different diastatic activity, a fact which has been known for many years (Lothrop and Paine,
1931). Various explanations for the low enzymatic activity of certain honeys have been proposed, such as a poor processing of nectar by the bees during an abundant nectar flow (Sipos, 1964), or seasonal activity of the pharyngeal glands (Halberstadt, 1980; Fluri et al, 1982). Even international standards include honeys with "a low natural content of enzymes" for which different limits are accepted (CAC, 1969).

Another extensively studied aspect of diastase activity in honey is its susceptibility to temperature and age of the honey. Although diastase sensitivity to heat and storage is not very high compared to saccharase (White et al, 1964), the measurement of diastatic activity is used to evaluate the freshness of honey. The qualitative parameters of the European standards (CAC, 1969) prescribe a diastatic index of no less than 8 on the Gothe scale and no less than 3 for honeys with a low natural enzyme content.

\footnotetext{
* Correspondence and reprints.
} 
The present study describes variability of diastase activity in relation to the botanical origin of the honey. In addition, to contribute to the simplification of the lengthy chemical analysis, the relationship between the diastatic index of a honey and the absorbance measured at the start of the analysis (5 $\mathrm{min}$ ) was quantified.

\section{MATERIALS AND METHODS}

During an extensive study of characteristics of Italian honeys (Accorti et al, 1986), 625 honeys of diverse botanical origins, produced in different years and in various Italian regions were analyzed for diastase. From these, 343 were chosen which, without doubt, could be classified as unifloral honeys. The choice was based on organoleptic characteristics (taste, smell, colour, physical state), physico-chemical properties (electrical conductivity, specific rotatory power, total acidity, $\mathrm{pH}$, glucide spectrum) and microscopic characteristics (qualitative and quantitative melissopalynological analysis) according to the limits described by Accorti et al (1986).

All the samples had been refrigerated $\left(-20^{\circ} \mathrm{C}\right)$ and were analyzed within 12 months of extraction. Their freshness at the time of analysis was verified through the determination of HMF $(<10 \mathrm{mg} / \mathrm{kg})$.
The selected samples were distributed as follows: 92 Castanea unifloral honeys, 76 Robinia, 29 Hedysarum, 23 Eucalyptus, 22 Arbutus, 18 Citrus, 15 Helianthus, 11 Thymus, 9 Erica, 9 Rhododendron, 9 Taraxacum and 30 Honeydew from spruce fir. The diastatic activity was determined for the entire assay according to the method of Schade et al (1958), modified by White and Pairent (1959) and by Hadorn (1961), accepted as the official method of analysis (CAC, 1969). Merck 1252 soluble starch was used after the blue value was verified. The results are expressed in Gothe scale units. The data collected were introduced into a program of simple descriptive processing.

\section{RESULTS}

The total variability of the diastatic index encountered in the assay (625 honeys) covered a vast range, from a minimum of zero to a maximum of 43.5 (average $18.3 \pm$ 9.1). Among the types analyzed, Erica, Robinia, Taraxacum and Citrus have a low diastatic index, with an average of 8-10 (fig 1 and table I). Particularly low values (average $5.2 \pm 3.0$ ) were encountered for the diastatic activity of Arbutus honeys, 2 samples of which gave a value of zero. These

Table I. Diastatic index values (expressed in Gothe scale units) for the principal Italian unifloral honeys.

\begin{tabular}{lrrrrr}
\hline Botanical origin & No samples & Mean & St dev & Min & Max \\
\hline Arbutus & 22 & 5.2 & 3.0 & 0 & 9.2 \\
Erica & 9 & 7.8 & 4.9 & 3.7 & 18.2 \\
Robinia & 76 & 8.4 & 2.9 & 3.1 & 15.0 \\
Taraxacum & 9 & 9.2 & 4.9 & 3.4 & 17.4 \\
Citrus & 18 & 9.8 & 3.0 & 3.4 & 16.3 \\
Rhododendron & 9 & 13.7 & 2.4 & 9.1 & 16.7 \\
Helianthus & 15 & 16.3 & 3.2 & 8.7 & 20.3 \\
Hedysarum & 29 & 19.8 & 6.0 & 12.5 & 33.3 \\
Honeydew & 30 & 22.9 & 6.9 & 10.9 & 34.1 \\
Castanea & 92 & 24.1 & 5.2 & 10.6 & 42.9 \\
Eucalyptus & 23 & 25.5 & 4.2 & 16.2 & 34.9 \\
Thymus & 11 & 33.1 & 4.7 & 24.3 & 39.0 \\
\hline
\end{tabular}




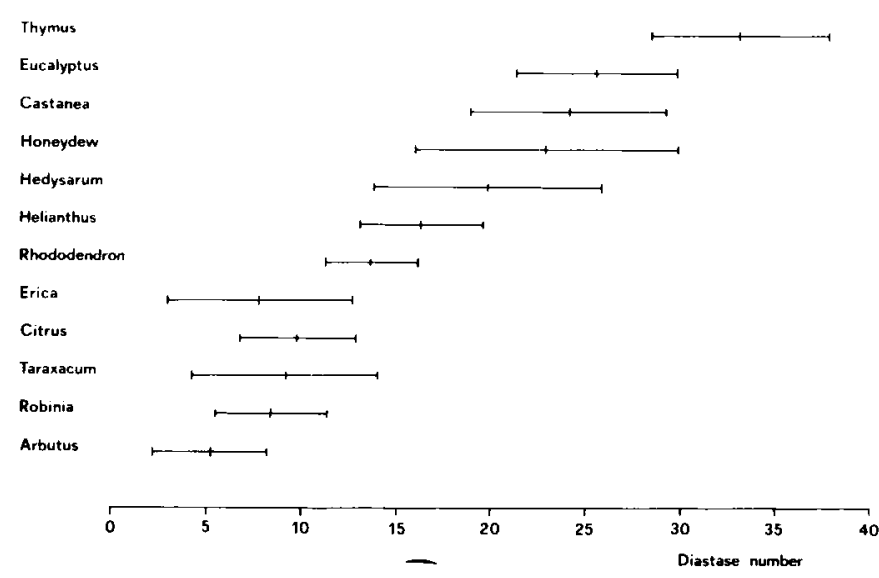

Fig 1. Diastatic activity (average \pm standard deviation) in the 12 groups of unifloral honeys analyzed.

honeys do not, therefore, come within the limit of 3 that the law prescribes for honeys with a low enzyme content, unlike the previous types for which the minimum values were always greater than 3 .

It must be pointed out that the samples were fresh and that none of them had been heated, as confirmed by the HMF values that were all extremely low. So, the obtained values can be considered as characteristic of the examined honeys and not dependent on external factors.

In the other unifloral types, Rhododendron and Helianthus showed moderate values (with an average of 13.7 and 16.3 respectively); Hedysarum, Castanea, Honeydew and Eucalyptus where characterized by a high diastatic index, with average values of 20-25. Diastatic activity was exceptionally high in Thymus honeys (average =$33.1 \pm 4.7$ ).

A comparison of these results with those reported in the literature shows that while numerous data are available for some honeys, they are very sparse or totally lacking for others. The general average diastatic index found for the entire as- say (18.3) coincides fairly well with that reported by White et al (1962) for an assay of some 500 American honeys (20.8), although their overall range covered much higher values (2.1-61.2).

For the unifloral types the most abundant data are found for Robinia and Citrus honeys. For Robinia, all authors give rather low values, similar to those found in this research (White et al, 1962; Fini and Sabatini, 1971; Marletto et al, 1977; Patetta et al, 1977; Ivanov, 1978). Low values have also been reported for Citrus honeys (White et al, 1962; Skender, 1972; Fini and Sabatini, 1974) and are supported by our results. Only those obtained by Serra Bonvehi et al (1986) indicate a higher average value, of $21.8 \pm 4.6$.

The scanty data available for the other unifloral types are often contradictory: for instance, the reported average diastatic index values for Eucalyptus honeys are 18 (Serra Bonvehi and Cañas Lloria, 1988), 21.9 (White et al, 1962), 29.6 (Langridge, 1966) and 43 (Fini and Sabatini, 1974), whereas for Honeydew honeys, White et al (1962) give 6.7 to 48.4 , and Serra Bonvehi et al (1986) give an average of $50.2 \pm 10.7$. 
The different values obtained by various authors may be attributed, at least in part, to the procedure adopted for the analysis, ie the type of starch used (Plazza and Accorti, 1981). In certain cases, however, we also encountered a considerable difference between minimum and maximum values within the same unifloral group, particularly for Castanea and Honeydew honeys (table I).

Values that grossly contradict ours and that are difficult to explain have been reported by Thrasyvoulou (1986), who in 125 samples of Greek honey encountered the lowest diastatic values for Thymus honeys, both for their overall range (4.535.2) and for their average (15.6). An explanation for such a great difference could be that the analysis may have concerned different species of Thymus. Also seasonal or bee-dependent factors might have played a role.

Relationship between initial diastatic index and absorbance

It takes a relatively long time to carry out analyses to determine diastatic activity, particularly for honeys with low values.
It is a well-known fact that the 5-min value gives an approximation of the end point (AOAC, 1980; Méthodes Officielles d'Analyse du Miel, 1977), and it was suggested that a definite relationship can be established between the diastatic index of a sample and the absorbance read at 5 min (Mohamedally, 1979, quoted by Wix, 1980). This could be a useful element since it would enable us to reduce the number of readings and the time necessary for analysis.

Consequently, since we had 281 paired observations of 5-min absorbance and diastase values we attempted to quantifiy this relationship. The results are expressed in the following linear equation (figure 2 ) :

$$
X_{2}=-70.1804-95.4183 X_{1}
$$

where: $X_{2}=$ diastatic index; $X_{1}=-$ absorbance at $5 \mathrm{~min}$.

The correlation between $X_{1}$ and $X_{2}$ is highly significant $(r=-0.94949, P<0.001)$, and also the angular coefficient is significantly different from $0(P<0.001)$. However, a more detailed analysis of the correlation within each group of unifloral honeys

Table II. Values of the regression between diastatic index and absorbance at 5 minutes for the different unifloral groups and their comparison with the values obtained for the total assay. ${ }^{* *}=$ significant for $P<0.001 ;$ ns $=$ not significant).

\begin{tabular}{|c|c|c|c|c|c|c|c|}
\hline $\begin{array}{c}\text { Botanical } \\
\text { origin }\end{array}$ & No & $a$ & $b$ & $r$ & $\underset{r}{\operatorname{sign}}$ & $t_{\mathrm{b}}$ & $\underset{b}{s i g n}$ \\
\hline Erica & 9 & 70.6480 & -96.0900 & -0.9591 & $\star *$ & 0.4654 & ns \\
\hline Hedysarum & 20 & 71.3045 & -96.6951 & -0.9719 & $\star \star$ & 0.4654 & ns \\
\hline Robinia & 52 & 67.0579 & -92.7342 & -0.9352 & $\star \star$ & -1.0252 & ns \\
\hline Honeydew & 49 & 71.0069 & -99.0081 & -0.9052 & ** & 1.2192 & ns \\
\hline Thymus & 10 & 70.6941 & -88.4858 & -0.8927 & $\star *$ & -1.6488 & ns \\
\hline Helianthus & 32 & 68.1127 & -89.2783 & -0.9344 & $\star *$ & -2.1569 & ns \\
\hline Castanea & 55 & 66.1425 & -87.1780 & -0.8597 & $\star \star$ & -2.7462 & $\star \star$ \\
\hline Eucalyptus & 16 & 76.8465 & -108.1093 & -0.9491 & ** & 3.7746 & $* *$ \\
\hline Citrus & 22 & 39.6945 & -46.7763 & -0.6414 & $\star \star$ & -12.9554 & $* *$ \\
\hline Total & 281 & 70.1804 & -95.4183 & 0.9495 & & & \\
\hline
\end{tabular}


shows that the lines representing Castanea, Eucalyptus, and particularly Citrus honeys (table II) are considerably detached from the general line. Arbutus, Rhododendron and Taraxacum honeys were represented by an insufficient number of data for any conclusion.

This induces us to consider that the phenomenon might be explained more satisfactorily by a non-linear model. However, since our objective is basically practical, we consider the linear model sufficient for forecasting the time intervals of the readings after the first at $5 \mathrm{~min}$.

\section{CONCLUSIONS}

Our data show that the diastatic activity of the honey is extremely variable among groups of unifloral honey. This variability is probably due to a series of uncontrollable intrinsic and extrinsic factors, and can be found also to a remarkably lesser degree, within the groups of unifloral honeys. However, despite this, the honeys with a low enzyme content are clearly distinguished from those with a moderate or high content.

An important remark must be made concerning the validity of the limit of 8 units ( 3

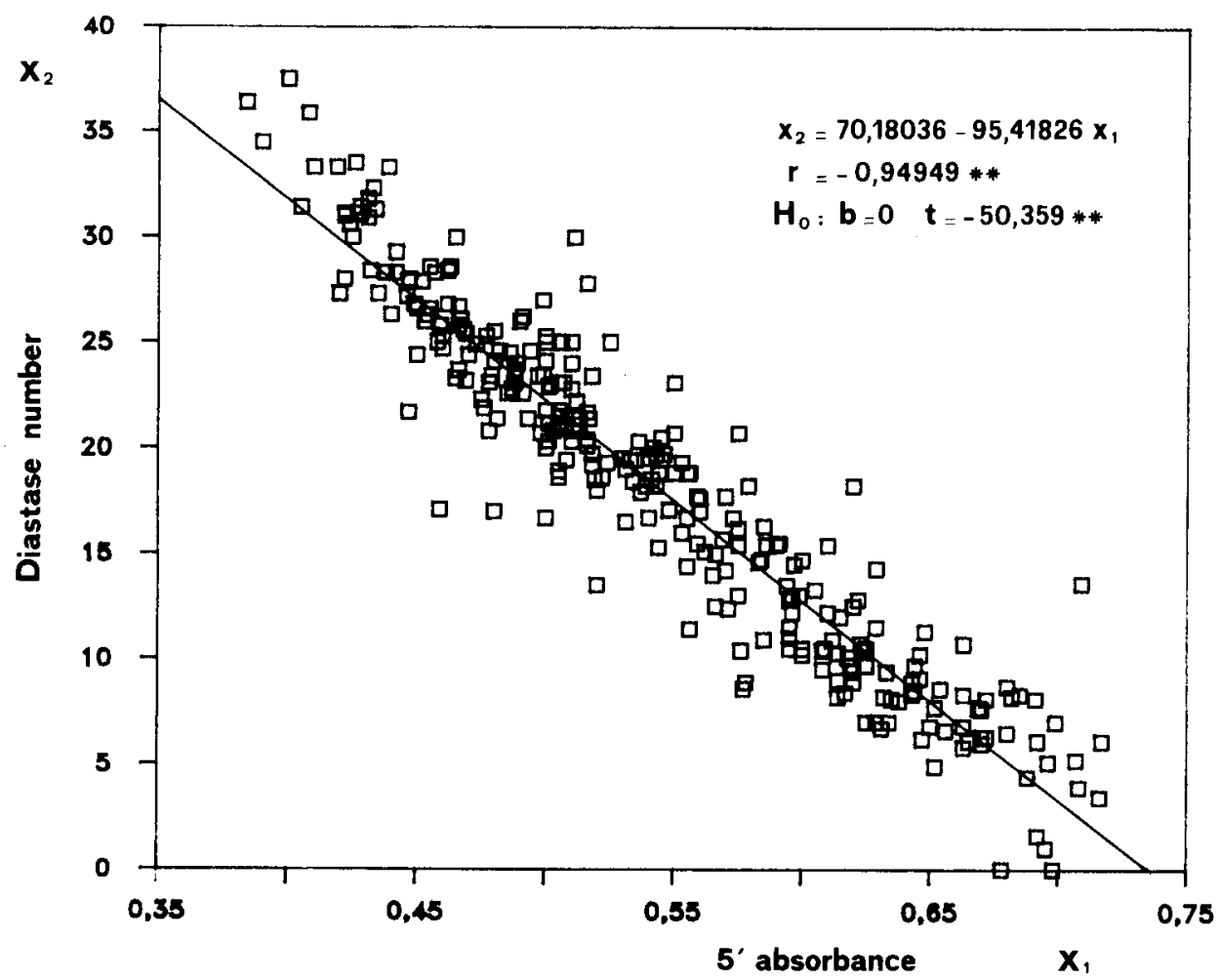

Fig 2. Relationship between diastatic index and absorbance at the first reading $(5 \mathrm{~min})$ on 281 couples of points. $X_{1}=$ absorbance at $5 \mathrm{~min} ; X_{2}=$ diastatic index. 
for honeys with a low natural enzyme content) prescribed for diastase activity by the international standards. With the large variation in values found in this study, the determination of diastatic activity cannot be considered a valid criterion to measure the freshness of honey. Unlike the HMF content which is theoretically zero in a fresh honey, it is impossible to know the original diastase content. Consequently, the same value can have a different meaning according to whether the original content was high or low. Unless other information is provided, it is therefore impossible to give a correct interpretation of the measured values.

We also consider it to be unfair discrimination that the international standards prescribe a different HMF limit for honeys with a low enzyme content $(15 \mathrm{mg} / \mathrm{kg}$ instead of 40). We are convinced that a limit of 40 is too high for any honey, to guarantee its freshness (Vorwohl, 1969, 1980; Fini and Sabatini, 1972; Piazza and Accorti, 1982; Persano Oddo et al, 1985; Accorti et al, 1986 ), but if this value is accepted it should be used for all honeys equally.

Résumé - Activité diastasique de quelques miels monofloraux. L'activité diastasique a été déterminée pour 12 groupes de miels monofloraux italiens : Castanea (châtaigner), Robinia (acacia), Hedysarum, Citrus, Eucalyptus, Arbutus (arbousier), Erica (bruyère), Helianthus (tournesol), Rhododendron, Taraxacum (pissenlit), Thymus (thym) et miellat. La grande variabilité de ce paramètre et le fait qu'il dépend fortement de l'origine botanique du miel ont été confirmés et quantifiés (fig 1, tableau I). En dehors des miels de Robinia et de Citrus, bien connus pour leur faible indice diastasique, de très faibles valeurs ont été trouvées pour les miels de Taraxacum, d'Erica et particulièrement d'Arbutus, chez lesquels la diastase peut être absente ou en tout cas inférieure au minimum de 3 prévu par les normes. Les miels d'Hedysarum, de miellat, d'Eucalyptus, de Castanea et encore plus de Thymus ont un indice diastasique élevé.

Cette grande variabilité nous conduit à reconsidérer ce paramètre comme indicateur de la fraicheur du miel, car les limites légales sont trop larges pour certains types de miels et trop restrictives pour d'autres. Finalement, la relation entre l'absorbance à la première lecture (à $5 \mathrm{~min}$ ) et l'indice diastasique a été étudiée et quantifiée (fig 3, tableau II). Elle est décrite de façon satisfaisante par l'équation linéaire :

$$
X_{2}=-70,1804-95,4185 X_{1}
$$

$\left(X_{2}=\right.$ nombre diastasique ; $X_{1}=$ absorbance à $5 \mathrm{~min}$ ).

Cela peut contribuer dans la pratique à simplifier cette analyse.

miel / activité enzymatique / amylase / absorbance

\section{Zusammenfassung - Diastase-Aktivität} in einigen Einblüten-Honigen. Für 12 Gruppen italienischer Einblüten-Honige wurde die Diastase-Aktivität bestimmt (Castanea, Robinia, Hedysarum, Citrus, Eucalyptus, Arbutus, Erica, Helianthus, Rhododendron, Taraxacum, Thymus und Honigtau).

Die große Variabilität dieser Eigenschaft und die große Abhängigkeit von der botanischen Herkunft dieser Honige wurde bestätigt und im einzelnen aufgegliedert (Abb 1, Tabelle I).

Außer für Robinia- und Citrus-Honige, deren niedrige Diastase-Werte seit langem bekannt sind, wurden auch für Taraxacum (Löwenzahn)-, Erica- und besonders für Arbutus (Erdbeerbaum)-Honige niedrige 
Werte gefunden; die Diastase kann bei diesen sogar fehlen oder niedriger als 3 sein, dem im Standard vorgeschriebenen Mindestwert. Hedysarum-, Honigtau, Eucalyptus, Castanea- und vor allem Thymus-Honige haben hohe Diastasewerte.

Diese große Variabilität zwingt uns, die Eignung dieser Eigenschaft als Indikator für die Frische des Honigs neu zu überdenken; denn die gesetzlichen Grenzen sind für einige Honigtypen zu weit, für andere wieder zu eng.

Schließlich wurde die Beziehung zwischen der ersten Ablesung (bei 5 Minuten) und dem Diastase-Index untersucht und quantifiziert (Abb 3 und Tabelle II). Sie kann zufriedenstellend beschrieben werden mit der linearen Gleichung

$$
X_{2}=-70,1804-95,4185 X_{1}
$$

$\left(X_{2}=\right.$ Diastasezahl; $X_{1}=$ Absorption bei 5).

Das kann zur praktischen Vereinfachung der Analyse beitragen.

\section{Honig / Enzymaktivität / Amylase / Absorption}

\section{REFERENCES}

Accorti M, Persano Oddo L, Piazza MG, Sabatini $A G$ (1986) Schede di caratterizzazione delle principali qualità di miele uniflorale italiano. Apicoltura 2, appendix

Ammon R (1949) Der Ursprung der Diastase des Bienenhonigs. Biochem Z 319, 295-299

AOAC (1980) Official Methods of Analysis, 527

Codex Alimentarius Commission (1969) Recommended European Regional Standard for Honey, FAO/OMS, CAC/RS 12, Italy

Fiehe J (1932) Über die Herkunft der Honigdiastase. Z Unters Lebensmittel 63, 329-331
Fini MA, Sabatini AG (1971) Caratterizzazione dei mieli italiani. I: mieli di Robinia pseudacacia. Quad Merceologia 10 (II) 115-132

Fini MA, Sabatini AG (1972) Indagine comparativa sul contenuto in idrossimetilfurfurale dei mieli destinati al consumo diretto. Sci Technol Aliment 2 (6), 375-379

Fini MA, Sabatini AG (1974) Osservazioni sulla composizione di alcuni tipi di miele della Sicilia. Sci Technol Aliment 4 (6), 349-355

Fluri $P$, Lüscher MM, Wille $H$, Gerig L (1982) Changes in weight of the pharyngeal gland and haemolymph titres of juvenile hormone, protein and vitellogenin in worker honey bees. J Insect Physiol 28 (1), 61-68

Gorbach G (1942) Zur Kenntnis der Stärkeverdaung durch die Biene. II. Mitteilung in der Reihe: Ernährungsphysiologische Studien an der Biene. Forschungsdienst 13, $67-78$

Gothe F (1914) Experimentelle Studien über Eigenschaften und Wirkungsweise der Honigdiastase sowie die Beurteilung des Honigs auf Grund seines Diastasegehaltes. $Z$ Unters Nahr Genussmittel 28 (6), 286-321

Hadorn H (1961) Zur Problematik der quantitativen Diastasebestimmung im Honig. Mitt Geb Lebensmittelunters Hyg 52 (2), 67-103

Halberstadt K (1980) Elektrophoretische Untersuchungen zur Sekretionstätigkeit der Hypopharynxdrüse der Honigbiene (Apis mellifera L). Insectes Soc 27 (1), 61-77

Ivanov TS (1978) Composition and properties of Bulgarian honey. Dissertation, Beekeeping Experimental Station, Sofia, Bulgaria

Langridge DF (1966) An investigation into some quality aspects of Victorian honey. $J$ Dep $\mathrm{Ag}$ ric Victoria 64, 81-90, 119-126, 139

Lothrop RE, Paine HS (1931) Diastatic activity of some American honeys. Ind Engng Chem Analyt 23, 71-74

Marletto F, Ferrazzi P, Patetta A, Manino A (1977) Caratterizazione dei mieli. Ind Aliment 16 (3), $111-115$

Méthodes Officielles d'Analyse du Miel (1977) 77-79, 11

Patetta A, Ferrazzi P, Manino A (1977) Caratteristiche fisico-chimiche dei mieli di Robinia (Robinia pseudoacacia L) piemontesi. Apic Mod 68 (5), 144-149 
Persano Oddo L, Accorti M, Piazza MG (1985) Recepimento in Italia della direttiva CEE sul miele: rispondenza del prodotto nazionale ai parametri previsti. Apicoltura 1, 141-156

Piazza MG, Accorti M (1981) Indice diastasico: scelta dell'amido. Apic Mod 72 (4), 141-146

Piazza MG, Accorti M (1982) L'HMF nei mieli prodotti e commerciati in Italia. Agric Ric (V) $14,50-52$

Rinaudo MT, Ponzetto C, Vidano C, Marletto F (1973) The origin of honey amylase. Comp Biochem Physiol 46B(2), 253-256

Serra Bonvehi J, Cañas Lloria S (1988) Caratteristiche fisico-chimiche, composizione e spettro pollinico del miele di Eucalipto (Eucalyptus spp) prodotto in Spagna. Apicoltura 4, 59-81

Serra Bonvehi J, Gomez Pajuelo A, Gonell Galindo $J$ (1986) Mieles monoflorales. Vida Apic 17, 25-31

Schade JE, Marsh GL, Eckert JE (1958) Diastase activity and hydroxy-methyl-furfural in honey and their usefulness in detecting heat alteration. Food Res 23 (5), 446-463

Sipos E (1964) The latest problems of honey evaluation. XIX Int. Beekeep. Congress, Prague 1963, 2, 643-646

Skender K (1972) La situation de l'apiculture algérienne et ses possibilités de développement. Algiers, Algeria: Mémoire d'Ingéniorat, Institut National Agronomique
Stadelmeier M, Bergner KG (1986) Proteine des Bienenhonigs. VII. Eigenschaften und Herkunft der Honigamylase. $Z$ Lebensm Unters Forsch 182, 196-199

Thrasyvoulou AT (1986) The use of HMF and diastase as criteria of quality of Greek honey. $J$ Apic Res 25 (3), 186-195

Vansell GH, Freeborn SB (1929) Preliminary report on the investigations of the source of diastase in honey. J Econ Entomol 22, 922926

Vorwohl G (1969) Der Hydroxymethylfurfuralgehalt in deutschen Honigen. $Z$ Bienenforsch 9 (11-12), 504-508

Vorwohl G (1980) Der Hydroxymethylfurfuralgehalt in Honigen der Bundesrepublik Deutschland. Auswertung der Messungen in der Jahren 1970-1979. Apidologie 11 (4), 375-383

White JW, Pairent FW (1959) Report on the analysis of honey. J Assoc Off Agric Chem 42, 341-348

White JW, Kushnir I, Subers MH (1964) Effect of storage and processing temperatures on honey quality. Food Technol 18 (4), 153-156

White JW, Riethof ML, Subers MH, Kushnir I (1962) Composition of American honeys. Tech Bull US Dep Agric, 1261

Wix $P$ (1980) The implication of the diastase and hydroxy-methylfurfuraldehyde (HMF) tests in the evaluation of honey quality in respect of marketing tropical honey within the European Economic Community (EEC). 2nd Int Conference, Apiculture in Tropical Climates, New Delhi, 1980, 711-720 